\title{
THE USE OF CIRC METHOD TOWARD \\ READING COMPREHENSION OF DESCRIPTIVE TEXT AT GRADE NINTH OF SMP NEGERI 1 GAUNG
}

\author{
Sy Khania Khulqi ${ }^{1}$, Samsul Amri², Maizarah ${ }^{3}$ \\ English Study Program \\ Universitas Islam Indragiri - Tembilahan Riau ${ }^{1,2,3}$
}

\begin{abstract}
Reading comprehension is the process of making meaning from the texts. In this study, the students' problems related to the students' difficulties in gaining information from the reading texts. CIRC (Cooperative Integrated Reading Composition) method was selected to solve those problems. Thus the main purpose of this current investigation is to test whether or not CIRC brings positive effects toward the students reading comprehension of descriptive texts. This is an experimental study, which was conducted at grade ninth students of SMP Negeri 1 Gaung. The samples consisted of 48 students. In collecting the data, the researcher used a test that is formed in the multiplechoice test. After conducting the research, it found the $t_{\text {observed }}$ was 7.14 , which was higher than the $t_{\text {table }}$ score in the degree of significance $1 \%$ and $5 \%(2.687<7.12>2.410)$. It means that the alternative hypothesis $\left(\mathrm{H}_{1}\right)$ of the research is accepted and the null hypothesis $\left(\mathrm{H}_{\mathrm{o}}\right)$ was rejected. In other words, the use of CIRC method toward students reading comprehension of descriptive text at grade ninth of SMP Negeri 1 Gaung is effective.
\end{abstract}

Keywords: Reading comprehension, Descriptive text, CIRC

\section{INTRODUCTION}

Based on the curriculum 2013, the students are required to master four basic skills of English namely: Listening, Speaking, Reading, and Writing. Reading is one of the important skill is needed to master by the students. Reading is a visual process to get information from the written texts. But reading is not easy for them, when the researcher came to the school and observed the students, many students found the difficulty in finding the topic and main idea, finding supporting details, analyze the reference, make an inference and they found the difficulty in finding the meaning of words. So, these problems influenced the students having low reading score including descriptive text. Actually, descriptive text is not too difficult, because the students always find it in daily activity, when they describe something, person, place or everything, so they have created a description. 
Descriptive text is a text which says what a person or a thing is like. However, those problems are found by the students in reading, so the students were getting difficulties to comprehend the descriptive text.

Dealing with the phenomenon found, the researcher needed to figure out the problems by applying an interesting and interactive method, namely Cooperative Integrated Reading Composition (CIRC). Hopefully, it makes the students will be easier to understand the descriptive text. It is a kind of Cooperative learning method. According Slavin in Suciidedee (2014:1) during using CIRC, the students are taught in reading groups and then return to mixed ability teams to work on a series of cognitively engaging activities, including partner reading, making predictions, identification of characters, settings, problem and problem solutions, summarization, vocabulary, reading comprehension exercises, and story-related writing. Students follow a sequence of teacher instruction, team practice, peer pre-assessments, assessment, and team recognition.

Therefore, the main objective of the study was to retest the effectiveness of CIRC method toward the students' reading comprehension of descriptive text. Additionally, a recommendation enables us to be provided after carrying out the research.

\section{LITERATURE REVIEW}

\section{Reading Comprehension}

Paris and Stahl (2005:83) state reading is generally described as involving two skills; decoding and comprehension. Decoding is an isolable ability, which can be taught and assessed in straightforward ways. Meanwhile, comprehension is a complex skill that depends on a variety of factors, context, and reading goals. Learners' factors, text factors, and instruction, all play a role. Moreover, Westwood (2008: 32) states that reading comprehension can be defined as an active thinking process which a reader intentionally constructs meaning to form a deep understanding of concept and information presented in a text. Then the readers must use their background knowledge to interpret, filter, organize, and reflect upon the incoming information from the passages. Efficient interpretation of the passages involves a combination of words recognition skills, linking of new information to prior knowledge, and application of 
appropriate strategies such as locating the main idea, making connections, questions, inferring, and predicting.

Then Martin (1991:1) conveys that the purpose of reading is to connect the idea on the page to what you already have known. If you do not know anything on the topic, the pouring word of the texts into your mind is like pouring water into your hand. Inline this point, Chamberlain (2006:39) divides two main goals of reading; reading for literacy experience, and reading to acquire and use information. Additionally, King and Stanley (2004:8) explain that there are five aspects of processing reading comprehension. They are finding factual information, finding the main idea, finding the meaning of vocabulary in context, identifying references, and making an inference. In brief, reading comprehension is the ability to read texts, process it and understand its meaning. It means that when one reads a text they should interpret the meaning of words and find the information from the text.

\section{Cooperative Integrated Reading and Composition (CIRC) Method}

CIRC is a comprehensive approach to reading and writing instruction for grades two to ninth. It consists of three principal elements: story-related activities, direct instructions in reading comprehension, and integrated writing or language arts. All of these activities, the students work in heterogeneous learning teams. All activities follow a regular cycle that involves teacher presentation, team practice, independent practice, peer reassessment, additional practice, testing, and team recognition (Slavin, 1983:2).

According to Saifullah in Sirkoni (2003:6), the advantages of learning CIRC method are as follow: students' experience and learning activities will always be relevant to their developmental level; activities are selected according to the students' interest and need; all learning activities are more meaningful for the students to survive much longer; integrated learning can grow and develop students' thinking skills, present a pragmatic activity based on the students' problems, and foster students' motivation toward a dynamic, optimal and appropriate learning; the students enable to develop social interaction; and it generates motivation to learn, expand horizons and aspirations of teacher in teaching. 
There are some steps in implementing CIRC method (Suciidedee, 2014:1). Firstly, the teacher makes a group with balance members heterogeneously (so there are students who have less and more ability). Secondly, the teacher gives a discourse/clipping according to the learning topic. Thirdly, the learners work together to solve problems or find information in discourse based on the teacher's instruction. Fourthly, the learners present and read the product of the group. Fifthly, teachers and learners conclude together. Finally, it is closing.

\section{Descriptive Text}

According to Zumakhsin (2005:21) in Nike Suryana, descriptive text is a text which describes the things that we see. It is also the same with Pardiyono (2007:32-34) says that descriptive text is a type of written text which has the specific function to give description an object (human and non-human). Moreover, Kane (2000:352) stated that the generic structure of the descriptive text is identification (introduction to the person, thing, animal, object or place), and description which describes parts, qualities, characteristics of the objects. Then Seyler (2004:81) adds that the language features of the descriptive text are using present tense, connective words in a text, adjective attributes, and linking verbs (is, am, are).

\section{Pahawang Island}

Pahawang Island is an island located in Punduh subdistrict Pasawaran district Lampung province. The island is divided into two they are Pahawang Big Island and Pahawang Small Island.

Pahawang Island has a lot and scenery of beautiful hills of green trees, white-sand beaches, crystal clear and fresh seawater are all you can enjoy on the island. It is suitable for those who like snorkeling. Moreover, in small Pahawang Island, there is a natural bridge called Tanjung Putus. Tanjung Putus connects between the Tanjung Putus Island and the Pahawang Small Island. Tanjung Putus can only be seen during low tide because when the tides rise, this natural bridge will be underwater. Tanjung Putus region is also one of the favorite diving spots for visitors. Small Pahawang Island can be reached approximately ten minutes from big Pahawang Island. Most visitors stay at Pahawang Big Island because most locals live there. 


\section{RESEARCH METHOD}

This is an experimental study where 48 students as samples A (Experiment) and B (Control) at IX grade of SMP Negeri 1 Gaung. Experimental research is the only type of research that can test hypotheses to establish cause - and - effect relationship. This research is pre-experimental research to know CIRC method in reading comprehension of descriptive text. The sample in this research is Purposive Sampling. The purpose of research can solve research problems and can provide more representative values. So, researching students in CIRC method toward reading comprehension of descriptive text using purposive sampling because of the purposive sampling will be easier to solve research problems.

For collecting the data, the writer only used one instrument, which is a test (Reading Test). The researcher for collecting data used multiple choices and a picture descriptive text, it is very useful to know the students' achievement in understanding material given by the teacher. Then in analyzing the data, the researcher used descriptive statistical analysis as well as the t-test. There two hypotheses would be tested:

1. $\mathrm{H}_{\mathrm{o}}$ : There is no significant effect of the using CIRC method toward student's reading comprehension of descriptive text at class IX SMP Negeri 1 Gaung.

2. $\mathrm{H}_{1}$ : There is a significant effect of the using CIRC method toward student's reading comprehension of descriptive text at class IX SMP Negeri 1 Gaung.

\section{FINDINGS AND DISCUSSION}

Looking back to the purpose of the study, it is to find out the effectiveness of the use of CIRC method toward reading comprehension of descriptive text in SMP Negeri 1 Gaung. After conducting the study, the researcher got the data in two classes; experimental class (IX-A) and control class (IX-B). The learning process of the experimental class was using CIRC method; meanwhile control class was using Group Discussion. Both techniques are sorts of cooperative learning. The tests were distributed before and after implementing the method.

Before the main tests were given, the researcher did the try-out test to examine the difficulty level of the items tests are given. The results of the try-out show that from 30 items there 20 items were accepted because the facility value was ranging from 0.30 
- 0.70. Meanwhile, 10 items were categorized as too easy items then it could not be used in the pre-test.

\section{Pre-test Results}

The researcher distributed the pre-test to both experimental and control classes. It purposes to measure the students' reading comprehension of descriptive text before implementing the CIRC method. The results could be presented as the following:

Table 1 The pre-test results of experimental class

\begin{tabular}{|c|c|c|c|c|c|}
\hline No. & $\begin{array}{c}\text { Interval } \\
\text { Score }\end{array}$ & Category & $\begin{array}{c}\text { Frequency } \\
(\mathrm{F})\end{array}$ & $\begin{array}{c}\text { Percentage } \\
(\%)\end{array}$ & $\begin{array}{c}\text { Mean } \\
\text { Score }\end{array}$ \\
\hline 1 & $80-100$ & Very Good & 4 & 17 & \\
\cline { 1 - 5 } 2 & $70-79$ & Good & 5 & 21 & \multirow{2}{*}{67.92} \\
\hline 3 & $60-69$ & Enough & 12 & 49.5 & \\
\hline 4 & $50-59$ & Low & 3 & 12.5 & \\
\hline 5 & $00-49$ & Very Low & 0 & 0 & \multirow{2}{*}{ Enough } \\
\hline \multicolumn{3}{|c|}{ Total } & 24 & 100 & \\
\hline
\end{tabular}

Dealing with the data above, it could be seen the students' reading comprehension skills of the experimental class before implementing the method. Only four students (17\%) were placed at a very good level. Then five students $(21 \%)$ got at a good level. Meanwhile, twelve students (49.5\%) were categorized in enough level. Last, there were three students (12.5\%) who gained at a low level. Even so, none of them was at a very low level. Overall, the students' reading comprehension of descriptive text was in enough level by the mean score 67.92. The results implied that they still had difficulties in finding information in the texts, which is needed to be solved.

Table 2 The pre-test results of the control class

\begin{tabular}{|c|c|c|c|c|c|}
\hline No. & $\begin{array}{c}\text { Interval } \\
\text { Score }\end{array}$ & Category & $\begin{array}{l}\text { Frequency } \\
(\mathrm{F})\end{array}$ & $\begin{array}{c}\text { Percentage } \\
(\%)\end{array}$ & $\begin{array}{l}\text { Mean } \\
\text { Score }\end{array}$ \\
\hline 1 & $80-100$ & Very Good & 1 & 4.6 & \multirow{5}{*}{65.83} \\
\hline 2 & $70-79$ & Good & 9 & 37.2 & \\
\hline 3 & $60-69$ & Enough & 10 & 41.3 & \\
\hline 4 & $50-59$ & Low & 3 & 12.3 & \\
\hline 5 & $00-49$ & Very Low & 1 & 4.6 & \\
\hline \multicolumn{3}{|c|}{ Total } & 24 & 100 & Enough \\
\hline
\end{tabular}

Referring to the table above, it could be discovered the students' reading comprehension skills of the control class in the pre-test. There was only one student (4.6\%) was categorized at a very good level. Next, there were nine students $(37.2 \%)$ who were at a good level. Then ten students (41.3\%) were at enough level. There were three students $(12.3 \%)$ who were placed in a low level. Last, only one of them was at a 
very low level. On the whole, the students' reading comprehension of descriptive text was in enough level by the mean score 65.83. The findings implied that they still obtained obstacles in comprehending the texts.

\section{Hypothesis testing of pre-test results}

After finding out the results of the pre-test, the researcher tested the hypothesis whether or not there is a significant difference between both classes; experimental class and control class. The results were as following:

Table 3. Independent samples test of pre-test

\begin{tabular}{|c|c|c|c|c|c|c|c|c|c|c|}
\hline & \multicolumn{2}{|c|}{$\begin{array}{c}\text { Levene's } \\
\text { Test for } \\
\text { Equality of } \\
\text { Variances }\end{array}$} & \multicolumn{7}{|c|}{ T-Test for Equality of Means } \\
\hline & & \multirow[b]{2}{*}{$\mathrm{F}$} & \multirow[b]{2}{*}{ Sig. } & \multirow[b]{2}{*}{$\mathrm{t}$} & \multirow[b]{2}{*}{ df } & \multirow[b]{2}{*}{$\begin{array}{l}\text { Sig. (2- } \\
\text { tailed) }\end{array}$} & \multirow[b]{2}{*}{$\begin{array}{c}\text { Mean } \\
\text { Difference }\end{array}$} & \multirow[b]{2}{*}{$\begin{array}{l}\text { Std. Error } \\
\text { Difference }\end{array}$} & \multicolumn{2}{|c|}{$\begin{array}{l}95 \% \text { Confidence } \\
\text { Interval of the } \\
\text { Difference }\end{array}$} \\
\hline & & & & & & & & & Lower & Upper \\
\hline \multirow{2}{*}{$\begin{array}{l}\text { The score of } \\
\text { Reading } \\
\text { Comprehension }\end{array}$} & $\begin{array}{l}\text { Equal variances } \\
\text { assumed }\end{array}$ & .725 & .399 & .748 & 46 & .458 & 2.08333 & 2.78426 & -3.52109 & 7.6877 \\
\hline & $\begin{array}{l}\text { Equal variances } \\
\text { not assumed }\end{array}$ & & & .748 & 45.35 & .458 & 2.08333 & 2.78426 & -3.52327 & 7.6899 \\
\hline
\end{tabular}

The data above describes that the data were distributed homogenously. It could be seen from the result of significant (sig.) of Levene's Test for Equality of Variances that was 0.399. It was higher than $0.05(0.399>0.05)$ which means the data was distributed homogenously in both classes; experimental and control. Moreover, the hypothesis testing of pre-test data shows that the significant (2-tailed) of the t-test for equality of means was 0.458 . It was greater than $0.05(0.458>0.05)$ which implies that the students' scores of pre-test in experimental and control classes were not different significantly. So the research could be continued as experimental research.

\section{Post-test results}

After teaching several meetings in both classes; experimental class (using CIRC method), and control class (using Group Discussion). The researcher administrated the pots-test. It aimed at measuring the effectiveness of the use of CIRC method toward the students' reading comprehension of descriptive text. The findings could be displayed as below: 
Table 4 The post-test results of experimental class

\begin{tabular}{|c|c|c|c|c|c|}
\hline No. & $\begin{array}{c}\text { Interval } \\
\text { Score }\end{array}$ & Category & $\begin{array}{c}\text { Frequency } \\
(\mathrm{F})\end{array}$ & $\begin{array}{c}\text { Percentage } \\
(\%)\end{array}$ & $\begin{array}{c}\text { Mean } \\
\text { Score }\end{array}$ \\
\hline 1 & $80-100$ & Very Good & 23 & 95.7 & \multirow{2}{*}{88.54} \\
\hline 2 & $70-79$ & Good & 1 & 4.3 & \\
\hline 3 & $60-69$ & Enough & 0 & 0 & \\
\hline 4 & $50-59$ & Low & 0 & 0 & \multirow{2}{*}{ Very Good } \\
\hline 5 & $00-49$ & Very Low & 0 & 0 & \\
\hline \multicolumn{7}{|c|}{ Total } & 24 & 100 & \\
\hline
\end{tabular}

The data above show that the students' reading comprehension skills of the experimental class after implementing the CIRC method improved significantly. There were twenty-three students $(95.7 \%)$ who were at a very good level. Then only one student $(4.3 \%)$ got at a good level. Meanwhile, none of them was in enough, low, and very low levels. Moreover, the students' reading comprehension of descriptive text was at a very good level by the mean score of 88.54 . The results implied that they had better skills in finding information in the passages.

Table 5 The post-test results of the control class

\begin{tabular}{|c|c|c|c|c|c|}
\hline No. & $\begin{array}{c}\text { Interval } \\
\text { Score }\end{array}$ & Category & $\begin{array}{c}\text { Frequency } \\
\text { (F) }\end{array}$ & $\begin{array}{c}\text { Percentage } \\
(\%)\end{array}$ & $\begin{array}{l}\text { Mean } \\
\text { Score }\end{array}$ \\
\hline 1 & $80-100$ & Very Good & 6 & 25 & \multirow{5}{*}{70.83} \\
\hline 2 & $70-79$ & Good & 8 & 33.3 & \\
\hline 3 & $60-69$ & Enough & 8 & 33.3 & \\
\hline 4 & $50-59$ & Low & 2 & 8.4 & \\
\hline 5 & $00-49$ & Very Low & 0 & 0 & \\
\hline \multicolumn{3}{|c|}{ Total } & 24 & 100 & Good \\
\hline
\end{tabular}

From the table above, it was found that the students' reading comprehension skills of the control class in the post-test also increased. There were six students (25\%) who were categorized at a very good level. Eight students $(33.3 \%)$ were placed at a good level; it was the same as in enough level which was also eight students (33.3\%). Furthermore, only two students $(8.4 \%)$ were at a low level, but none of them was at a very low level. In all, their reading comprehension of descriptive text was categorized as a good level by the mean score 70.83 , which was better results than in the pre-test. The researcher implied that they could comprehend the texts well. 


\section{Hypothesis testing of post-test results}

After determining the results of the post-test, the researcher tested the hypothesis of whether or not there is a significant effect of the treatment given (CIRC method) toward students' reading comprehension of the descriptive text. The results were as following:

Table 6 Independent samples test of the post-test

\begin{tabular}{|c|c|c|c|c|c|c|c|c|c|c|}
\hline & \multicolumn{2}{|c|}{\begin{tabular}{|c|} 
Levene's \\
Test for \\
Equality of \\
Variances
\end{tabular}} & \multicolumn{7}{|c|}{ T-Test for Equality of Means } \\
\hline & & \multirow[b]{2}{*}{$\mathrm{F}$} & \multirow[b]{2}{*}{ Sig. } & \multirow[b]{2}{*}{$\mathrm{t}$} & \multirow[b]{2}{*}{ df } & \multirow[b]{2}{*}{$\begin{array}{l}\text { Sig. }(2- \\
\text { tailed) }\end{array}$} & \multirow[b]{2}{*}{$\begin{array}{c}\text { Mean } \\
\text { Difference }\end{array}$} & \multirow[b]{2}{*}{$\begin{array}{l}\text { Std. Error } \\
\text { Difference }\end{array}$} & \multicolumn{2}{|c|}{$\begin{array}{l}\text { 95\% Confidence } \\
\text { Interval of the } \\
\text { Difference }\end{array}$} \\
\hline & & & & & & & & & Lower & Upper \\
\hline \multirow{2}{*}{$\begin{array}{l}\text { The score of } \\
\text { Reading } \\
\text { Comprehension }\end{array}$} & $\begin{array}{l}\text { Equal variances } \\
\text { assumed }\end{array}$ & 1.46 & .232 & 7.12 & 46 & .000 & 17.70833 & 2.48448 & 12.7073 & 22.7093 \\
\hline & $\begin{array}{l}\text { Equal variances } \\
\text { not assumed }\end{array}$ & & & 7.12 & 41.945 & .000 & 17.70833 & 2.48448 & 12.6942 & 22.7224 \\
\hline
\end{tabular}

Based on the table above, it was factually that the data were distributed homogenously. It could be seen from the result of significant (sig.) of Levene's Test for Equality of Variances that was 0.232 . It was greater than $0.05(0.232>0.05)$ that implies the data were distributed homogenously in both classes; experimental and control. Furthermore, the hypothesis testing of post-test data describes that the significant (2tailed) of t-test for equality of means was 0.000 . It was less than $0.05(0.000<0.05)$ which means that the students' score of post-test in experimental and control classes were different significantly.

The result of the statistic calculation indicates that the value of t-o is 7.12 and the value of the degree of freedom (df) was 46. In this research, the researcher used the degree of significance of $5 \%$ and $1 \%$. The researcher used df $=46$. Meanwhile, the degree of significance of $5 \%$ is 2.687 and $1 \%$ is 2.410 . After obtaining $t_{\text {observed }}$, the writer compared it with each value of the degree of significance, the result is $t_{\text {table }}<t_{\text {observed }}>t_{\text {table }}=2.687<7.14>2.410$. Since $t_{\text {observed }}$ score is bigger than $t_{\text {table }}$, it means that the alternative hypothesis $(\mathrm{Ha})$ of research is accepted and the null hypothesis (Ho) is rejected. In other words, it means that there is a significant effect of the students' reading comprehension of descriptive text who are taught using CIRC and who are taught using non-CIRC. 


\section{CONCLUSION}

This study was to investigate if the use of CIRC method could bring effective results toward reading comprehension of descriptive text. After conducting the research SMP Negeri 1 Gaung, the researcher found the result is $t_{\text {observed }}$ is greater than $t_{\text {table }}$ $(2.687<7.12>2.410)$ in the degree of significance $5 \%$ and $1 \%$. it means that the alternative hypothesis(Ha) of research is accepted and the null hypothesis (Ho) is rejected. It also means that the use of CIRC method toward reading comprehension of descriptive text at IX grade of SMP Negeri 1 Gaung is effective.

\section{REFERENCES}

Adams, M. J. (1990). Beginning to read: Reading Comprehension and Learning Descriptive Text about CIRC. Cambridge, MA: MIT Press.

Anderson, R. C. (1996). Research Foundations to Support Wide Reading. In V.

Anderson, et.al (1985).Becoming a nation of readers: The descriptive of the Commission on Reading. Washington DC: The National Institute of Education.

Arikunto (2010). Resulted of The Data Processing in Test Hypothesis. Indonesia

Broughton, Geoffrey. (2003).Teaching English as a Foreign Language in Silent Way. New York: Rout ledge Education Books.

Brown, H. Douglas. (2000).Principles of Language Learning and Teaching. USA: San Francisco State University.

Chambers, Ellie. (2006). Teaching and Learning Reading Comprehension. British: SAGE Publications Ltd.

Creswell, John. (2005). Population a Group of Individuals and Sample Is Sub-Group of Target Population. Indonesia

David. Johnson. (2000). Cooperative Learning Methods: A Meta-Analysis. Minnesota: University of Minnesota.

Fraenkel, J. \& Wallen, N. (1993). How to Design and evaluate research in education. (2nd ed). New York: McGraw-Hill Inc.

Greaney (Ed.), (1992) Promoting reading in developing countries. Newark, DE: International Reading Association. 
Gay, L.R. dan Diehl, P.L. (1992), Research Methods for Learning Reading Comprehension and. Management, MacMillan Publishing Company, New York

Hair, et.al (2006). Multivariate Data Analysis (6 Ed). New Jersey: Prentice-Hall

Hager, Ashley. (2005). Understanding What Reading Is All About. Cambridge: Harvard Graduate School of Education.

Harmer, Jeremy. (2001). How to Teach English. England: Longman Group, Ltd.

Harmer. (2007). The Practice of English Language Teaching. England: Longman Group, Ltd.

Heinemann. (2009). Reading Process. Portsmouth: Miami University-Oxford.

Hatch and Farhady, (1982) Determining the Means of Both Groups Experimental and Control. Analysis of Data

Irwin, J.W. (2007). Teaching Reading Comprehension Processes.America: Pearson Education, Inc.

Kristin, et.al. (2010). Teaching Reading to English Language Learners. New York: The Guilford Press.

National Reading Panel. (2000). What is Reading Comprehension and why is it Important.NC: National Center.

Pressley. (2002). Teaching Reading. Bureau: International of Education. 